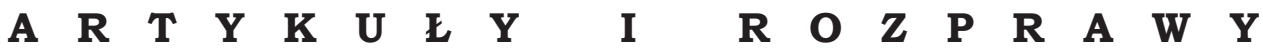

Przemystaw E. Gębal

DOI: $10.33896 /$ PorJ.2021.10.1

(Uniwersytet Warszawski, Politechnika Ślaska, Gliwice

e-mail: p.gebal@uw.edu.pl)

ORCID: 0000-0002-4335-5886

\section{PONAD FILOLOGIĄ I LINGWISTYKĄ STOSOWANĄ. POLONISTYKA STOSOWANA JAKO INTEGRUJĄCA KONCEPCJA BADAWCZA}

\section{WPROWADZENIE. UJĘCIE KRYTYCZNE}

Podejmując refleksję na temat rozwoju i funkcjonowania danego obszaru badań empirycznych, warto na wstępie określić sposób oraz pozycje jej uprawiania, wraz $z$ uwzględnieniem przyjętej w rozważaniach perspektywy krytycznej. Tak sformułowane podejście jasno ukaże cel opracowania niniejszego tekstu, jakim jest dalszy rozwój akademickiej koncepcji polonistyki stosowanej, której twórca pierwotnej wersji jest Stanisław Dubisz z Uniwersytetu Warszawskiego.

Prowadzone w tym tekście rozważania wpisuja się w nurt krytyki hermeneutycznej, która postrzega konkretne zjawiska $z$ perspektywy ich ciagłego stawania się na nowo, ich nieustającego poddawania się interpretacji. Zasadniczym celem tak prowadzonej dyskusji jest $z$ jednej strony gotowość i chęć lepszego rozumienia owych zjawisk, $z$ drugiej zaś inspirowanie innych do myślenia i podejmowania trudu głębszej refleksji [Kwaśnica 1990; Rainko 1990; Bauman 2006]. Próba zrozumienia szerokiego kontekstu wprowadzania koncepcji polonistyki stosowanej do polskiej rzeczywistości akademickiej oraz podjęcie dyskusji inspirującej do dalszego rozwoju tej praktyki badawczej uprawiane przez autora niniejszego tekstu sytuuja go na pozycji swoistego outsidera [Walzer 2002; Bauman 2006]. Nie uczestniczył on bowiem w najistotniejszym, początkowym procesie rozwoju opisywanych praktyk. Poznajac je i odkrywajacc ich potencjał akademicki, stara się jednak zachować swój dystans do nich, przejawiający się przede wszystkim w postaci emocjonalnej niezależności. W przeciwieństwie do tzw. tubylców, czyli długoletnich wspólpracowników Stanisława Dubisza, nie znał on bowiem kultury oraz zasad sterujacych rozwojem opisywanego obszaru akademickiego. Prezentuje zatem rozważania i wnioski własne, pewnie często oderwane od ugruntowanej wśród tubylców tradycji myślowej. Ów kontekst zapewnia wprowadzenie ujęcia krytycznego, stanowiącego metodologiczne zaplecze podejmowanych rozważań. 


\section{POLSKA LINGWISTYKA STOSOWANA PUNKTEM ODNIESIENIA DLA POLONISTYKI STOSOWANEJ}

Choć sami poloniści stosowani nie poświęcają obecnie niestety zbyt wiele czasu na podejmowanie rozważań na temat akademickiej lokalizacji uprawianego przez nich obszaru badawczego w kontekście nauk humanistycznych, bez trudu można przyjąc, iż najbliżej im do polskiej lingwistyki stosowanej.

Ten obszar akademicki, rozwijany głównie w kręgach neofilologicznych, uprawiany jest zwykle w odniesieniu do dwóch tradycji epistemologicznych: polskiej i zachodnioeuropejskiej (stanowiącej kontynuację tradycji amerykańskiej). Pierwsza ze wspomnianych ścieżek odwołuje się bezpośrednio do działalności badaczy skupionych wokół Ludwika Zabrockiego z Uniwersytetu Adama Mickiewicza w Poznaniu, uznawanego za inicjatora tego kierunku rozwoju interesującej nas dziedziny. Podjęta jeszcze w latach 50. minionego stulecia droga zainteresowała pierwotnie głównie środowisko germanistów, choć $z$ czasem utożsamiało się $z$ nią coraz więcej reprezentantów innych neofilologii. $Z$ dzisiejszej perspektywy mówi się o ukonstytuowaniu się dwóch szkół naukowych lingwistyki stosowanej w tym nurcie epistemologicznym. Szkoła poznańska jest skupiona wokół Ludwika Zabrockiego, kontynuowana także przez jego uczniów, w pierwszej kolejności Waldemara Pfeiffera, związanego instytucjonalnie $z$ Katedrą Glottodydaktyki i Translatoryki UAM (dziś Instytut Lingwistyki Stosowanej). Druga to szkoła warszawska, której głównym reprezentantem był Franciszek Grucza, także uczeń Ludwika Zabrockiego, kojarzona pierwotnie $z$ działalnościa Instytutu Lingwistyki Stosowanej UW (do końca lat 90. minionego stulecia), a w ostatnich latach także innych jednostek dydaktyczno-naukowych, skupionych wokół Wydziału Lingwistyki Stosowanej.

Czuwający bezpośrednio nad rozwojem tego nurtu lingwistyki stosowanej F. Grucza dużą część swojej działalności naukowej poświęcił rozważaniom i metarefleksjom, budując filozoficzne podłoże rozwoju całego obszaru badawczego. Całkiem niedawno zwracał jednak jeszcze uwage na brak jednolitej koncepcji rozważań rozgraniczających lingwistykę czysta, czyli teoretyczna, od stosowanej [Grucza 2007, 42]. Pierwsze lata działalności szkoły warszawskiej skupiły się, poza cyklem rozważań o charakterze metapoznawczym w odniesieniu do promowanej koncepcji lingwistyki stosowanej, na rozwoju glottodydaktyki i translatoryki. Choć stanowiły one swoiste subdziedziny lingwistyki stosowanej, uprawiane w ramach działalności naukowej i dydaktycznej warszawskiego ILS, zgodnie $z$ wizjami F. Gruczy miały docelowo stać się autonomicznymi bytami naukowymi, co w dużym stopniu udało się osiagnąć. Jeśli nie $\mathrm{w}$ formalnym opisie struktury polskiej humanistyki, to na pewno w sposobie postrzegania tych obszarów przez środowisko reprezentujące nauki humanistyczne i społeczne. Powiazania glottodydaktyki i transla- 
toryki z lingwistyką stosowaną miały polegać jedynie, zdaniem F. Gruczy, na wykorzystywaniu zdobyczy tej ostatniej, która co prawda zapoczątkowała akademickie funkcjonowanie obu dziedzin, ale nigdy nie uzurpowała sobie prawa do stanowienia obszaru nadrzędnego w stosunku do nich w szeroko pojętym wymiarze nauk humanistycznych. Owe zdobycze odnosiły się w pierwszej kolejności do zakrojonych rozważań i badań $\mathrm{w}$ zakresie komunikacji w jej różnych wymiarach lingwistycznych. Tak nakreślona jeszcze w latach 70. minionego stulecia wizja znalazła potwierdzenie w określeniu celów lingwistyki stosowanej przez F. Gruczę $\mathrm{w}$ roku 2007. Zgodnie $z$ nia lingwistyka stosowana to

dziedzina zajmująca się działalnością naukowa, której celem jest wykorzystanie czy zastosowanie zdobyczy językoznawstwa dla usprawnienia czy wręcz stworzenia (...) warunków komunikacji językowej. (...) Badania prowadzone [sa - PG] na bazie informacji zgromadzonych przez lingwistykę czysta nad sposobami tworzenia, przywracania oraz ulepszania warunków komunikacji językowej, a także nad możliwościami zwiększania efektywności tych sposobów [Grucza 2007].

Wyniki tak sformułowanych dociekań empirycznych zapewne przydadza się dalszemu rozwojowi lingwistyki stosowanej oraz rozwijającej się w jej ramach autonomicznej glottodydaktyce i translatoryce, które w obszarze nauk zajmujących się procesami komunikacji uzupełniają dzisiaj także m.in. fonetyka stosowana, logopedia i lingwistyczna afazjologia, ortografia i ortoepia, kultura języka (polskiego), leksykografia, terminologia - języki specjalistyczne, zaliczane przez F. Gruczę do dziedzin spokrewnionych $z$ lingwistyka stosowana [Grucza 2007]. Biorac pod uwage dzisiejsze szerokie zainteresowania lingwistyki stosowanej, znacznie rozszerzoną typologie jej subdyscyplin prezentuje w swoim tekście E. Gruszczyńska [2014, 95], zaliczając do nich: metodykę i technologię nauczania języka ojczystego (w tym tworzenie materiałów), metodykę i technologie nauczania języków obcych (w tym tworzenie materiałów), stylistykę praktyczna (języka ojczystego, języków obcych i porównawcza), logopedię (języka ojczystego i języków obcych), leksykografię (jedno- i wielojęzyczna), retorykę (w języku ojczystym, w językach obcych i porównawcza), werbalna i niewerbalna komunikacje językowa (ojczysta i obca, w tym za pomoca narzędzi elektronicznych), analizę dyskursu (ojczystego i obcojęzycznego), politykę językowa, antropolingwistykę (na gruncie języka ojczystego, języka obcego i porównawcza), psycholingwistyke (na gruncie języka ojczystego, języka obcego i porównawcza), socjolingwistykę (na gruncie języka ojczystego, języka obcego i porównawcza), język mediów, w tym propagandy i perswazji (na gruncie języka ojczystego, języka obcego i porównawczy), języki specjalistyczne (na gruncie języka ojczystego, języka obcego i porównawczo), lingwistykę normatywna (w tym kulturę języka ojczystego, języków obcych i porównawcza), inżynierię lingwistyczna, w tym lingwistykę korpusowa (języka ojczystego, języka obcego i porównawcza), język uproszczony (w odniesieniu do języka oj- 
czystego, języka obcego i porównawczo). Nietrudno zauważyć, że pewna ich część ma charakter polonistyczny. Trudno sobie wyobrazić ich uprawianie w kręgach lingwistów o inklinacjach neofilologicznych.

Kolejne opracowania F. Gruczy podejmowały zwykle kwestie wizji rozwoju lingwistyki (stosowanej) $z$ uwzględnieniem nowych, humanistycznie zorientowanych punktów odniesienia o charakterze kulturologicznym $i$, następnie, antropocentrycznym. Nowe nakreślane wizje wzmacniały różnice między lingwistyką czystą (teoretyczna) a stosowana, zaniedbujacc jednak refleksje nad sposobem pojmowania epistemologicznego i ontologicznego tej drugiej.

Druga rozwijana w Polsce koncepcja lingwistyki stosowanej, reprezentowana pierwotnie głównie w środowisku anglistów, odnosiła się bezpośrednio do amerykańskiej i zachodnioeuropejskiej (głównie brytyjskiej) tradycji rozwoju tej dziedziny [Duszak 1998; Duszak, Fairclough 2008; Duszak, House, Kumięga 2010]. Choć, chcąc nie chcąc, uwikłana w opisywany rozwój polskiej koncepcji lingwistyki stosowanej, podażała zwykle kierunkami nakreślanymi przez tzw. lingwistyki łącznikowe, scalające od samego początku ich rozwoju badania lingwistyczne $z$ innymi dziedzinami nauk, pierwotnie humanistycznymi i społecznymi, z czasem także innej natury badawczej. Owo połączenie zapewniało zrazu orientację stosowana, pojmowana zwykle jako pragmatyczne, interdyscyplinarne powiązania i współpracę między dziedzinami:

To nie gramatyka, a nawet nie modele języka, stanowi o sile współczesnej lingwistyki, ale jej pragmatyczne, empiryczne i interdyscyplinarne nachylenie badawcze [Duszak 2009].

Owe lingwistyki łacznikowe to m.in. socjolingwistyka, psycholingwistyka, pragmalingwistyka, neurolingwistyka, etnolingwistyka, ale również lingwistyka tekstu, krytyczna analiza dyskursu, lingwistyka krytyczna, lingwistyka komputerowa, cyfrowa czy nawet komunikacja literacka. Rozwój każdej z nich wspierał pierwotnie nakreślone przestrzenie działania lingwistyki stosowanej, do których od samego początku należały m.in. przyswajanie, uczenie się i nauczanie języków oraz tłumaczenia, niekreowane jednak zwykle, jak w wypadku polskich koncepcji na autonomiczne obszary naukowe. $Z$ czasem jednak ich wymiar aplikatywny pożytkowany był dla rozwoju innych obszarów naukowych. Wspomina o nich Anna Duszak, która w ich uprawianiu dopatruje się także oddziaływania koncepcji lingwistyki teoretycznej (określanej mianem czystej przez F. Gruczę):

Tego, czym jest współczesna lingwistyka, szukać trzeba także pod hasłami takimi, jak multimodalna analiza dyskursu, krytyczna analiza dyskursu, pragmatyka, semiotyka społeczna, czy nowa retoryka międzykulturowa. Takie odmiany lingwistyki tworza własne kanony wiedzy. Zaznacza się dynamiczny rozwój lingwistyki antropologicznej, pragmatyki, czy studiów nad tekstem i dyskursem [Duszak 2009, 12]. 
A. Duszak wydawała się stanowczo opowiadać za szerszym wydzieleniem studiów lingwistycznych $z$ kanonu wciąz tradycyjnie uprawianej w Polsce neofilologii:

Jednakże w mojej opinii obecny stan rzeczy skutkuje niedobra sytuacją lingwistyki w programach studiów językowych, co w przyszłości stanowić może zagrożenie dla akademickiego charakteru dydaktyki na tym obszarze. (...) Ważne jest tworzenie przestrzeni dydaktycznej dla specjalizacji lingwistycznych, nawet jeżeli miałyby one funkcjonować jako studia elitarne, adresowane do mniej licznej grupy osób zainteresowanych lingwistyką i jej zastosowaniami w badaniach społecznych [tamże].

Należy pamiętać, iż w czasie powstania cytowanego tekstu A. Duszak, i w dalszym ciagu, standardy kształcenia na kierunku „lingwistyka stosowana" w niewielkim stopniu odbiegaja od tradycyjnie pojmowanego kształcenia neofilologicznego, $z$ nieco większym udziałem $\mathrm{w}$ programach studiów zajęć zahaczających o lingwistyki łącznikowe.

Wraz z rozwojem technologii informatycznych opisywane wyżej koncepcje uzupełniła lingwistyka komputerowa, łaczacca dociekania i badania lingwistyczne $z$ informatyka, automatyka i innymi pokrewnymi naukami technicznymi (coraz częściej nazywanymi technologicznymi). Określana często także mianem lingwistyki informatycznej, cyfrowej lub inżynierii lingwistycznej wyraźnie odzwierciedla jej interdyscyplinarna łączliwość. Wciąż jednak w rzeczywistości polskiej, w kwestii badań języka naturalnego $z$ punktu widzenia potrzeb jego przetwarzania i modelowania metodami komputerowymi i cyfrowymi, nierozwiazana pozostaje kwestia akademickiego postrzegania lingwistyki komputerowej. Nie chodzi tutaj tylko o jej odniesienie do którejś $z$ dwóch tradycji epistemologicznych, ale w ogóle o jej miejsce w przestrzeni polskiej akademickiej lingwistyki (stosowanej). Lingwistyka komputerowa często przez lingwistów nie jest traktowana jako dyscyplina warta humanistycznej refleksji językoznawczej i uznawana za dziedzinę techniczna (technologiczna). Specyfika większości dotychczas realizowanych polskich projektów koncentrujących się na przetwarzaniu języka jednak wyraźnie pokazuje, że działalność ta jest raczej domeną lingwistyki informatycznej, a nie informatyki lingwistycznej [Ogrodniczuk 2017]. Odzwierciedla to fakt dominacji w owych projektach prac o charakterze lingwistycznym. Wspomniana interdyscyplinarność wydaje się w tym wypadku napędzać sztuczną konkurencję, niesłużąca włączaniu lingwistyki informatycznej do refleksji nad samą lingwistyka i lingwistyką stosowana, choć te $z$ coraz większym zainteresowaniem przyglądaja się technologiom informatycznym, choćby pod postacią prężnie rozwijanych, i im bliższych, badań korpusowych, które bez jakichkolwiek wątpliwości w środowisku polskich lingwistów uznawane będą za dociekania natury lingwistyki stosowanej. Być może pojawienie się pierwszych w Polsce specjalizacji w zakresie lingwistyki komputerowej (cyfrowej) w ramach studiów lingwistycznych (UAM w Poznaniu) przysłużą się akademickiemu zbliżeniu jej do lingwistyki 
stosowanej. Coraz większe zainteresowanie nimi w kręgach polonistów powinno także ułatwić ich uznanie na szerokiej arenie humanistyki.

W nakreślonej pierwotnie przez Stanisława Dubisza koncepcji polonistyki stosowanej znaleźć można przestrzeń do realizacji wszystkich wymienionych wyżej obszarów lingwistycznych w kontekście języka polskiego. Choć znaczna ich część wydaje się już zagospodarowywana, są jeszcze obszary niecieszące się zbyt dużym zainteresowaniem wśród polonistów. Intencje S. Dubisza wydaja się mieć zatem w tej kwestii charakter programujący, rozwijający cały obszar lingwistyki polonistycznej, z uwzględnieniem obu opisanych tradycji epistemologicznych oraz lingwistyki komputerowej. Wprowadzenie tego typu rozważań do dyskusji nad rozwojem polonistyki należy odebrać jako jasną propozycję wizji nowoczesnego, bardziej zorientowanego aplikatywnie, akademickiego uprawiania językoznawstwa polonistycznego.

\section{POLONISTYKA STOSOWANA W UJĘCIU STANISEAWA DUBISZA}

Pierwotna koncepcja polonistyki stosowanej skonstruowana została przez związanego $z$ warszawska polonistyką Stanisława Dubisza w pierwszej dekadzie XXI wieku. Stanowi ona obszar badawczy i dydaktyczna praktykę uniwersytecką łączaca tradycyjnie uprawianą filologiczna polonistykę $z$ innymi dziedzinami naukowymi $z$ zachowaniem zasad interi transdyscyplinarnej współpracy akademickiej w celu zaspokajania potrzeb wynikających $z$ realizacji zadań przypisanych konkretnym zawodom wymagającym przygotowania polonistycznego, zarówno w wymiarze językoznawczym, jak i literaturo- i kulturoznawczym. Formalne akademickie instytucjonalne zaistnienie polonistyki stosowanej datuje się na rok 2007, w którym powołano do życia nowa jednostkę w ramach Wydziału Polonistyki UW, która jest Instytut Polonistyki Stosowanej. Sam instytut powstał na wniosek grupy inicjatywnej, która stanowili profesorowie i doktorzy habilitowani Instytutu Literatury Polskiej i Instytutu Języka Polskiego: prof. prof. Danuta Knysz-Tomaszewska, Jakub Lichański, Bogdan Owczarek, Elżbieta Sękowska, Józef Porayski-Pomsta i Zofia Zaron. Sam projekt utworzenia Instytutu sformułowany został w ramach prac grupy inicjatywnej w lutym 2007 roku. W swoich założeniach uwzględniał zarysowane wcześniej kierunki rozwoju koncepcji akademickiej polonistyki stosowanej, opisywanej przez Stanisława Dubisza.

W myśl jego wizji polonistyka stosowana stanowić ma swoista ścieżkę pośrednia między uprawiana od lat filologia polska, realizowana w sposób filologiczny, choć uzupełniającą coraz częściej tradycyjne literaturoznawstwo i językoznawstwo o kulturoznawstwo, a zorientowanym glottodydaktycznie językoznawstwem i kulturoznawstwem stosowanym, wspierającym nauczanie języka polskiego jako obcego i kultury polskiej jako obcej. Przekładając ową wizję na grunt realizacji kształcenia 
akademickiego, dostrzeżemy sens szerszego uprawiania zorientowanej pragmatycznie polonistyki w środowisku międzykulturowym, w którym spotykaja się studenci polscy z zagranicznymi. Należy przyjąć, że w tej koncepcji transfer podejścia glottodydaktycznego miał otworzyć tradycyjnie uprawiana polonistykę na nowe obszary lingwistyki stosowanej, które w glottodydaktyce, czyli badaniach lingwistycznych nad uczeniem się i nauczaniem języków obcych, obecne już były wcześniej i kształtowały w dużym stopniu całą lingwistykę stosowaną.

Ucieleśnienie zorientowanej bardziej pragmatycznie i lingwistycznie wizji filologii polskiej w postaci polonistyki stosowanej stało się rezultatem pewnego mentalnego procesu akademickiego, który miał na celu zmianę sposobu myślenia i realizacji filologicznych studiów polonistycznych czy w ogóle szerzej studiów humanistycznych [Dubisz 2013]. Powstanie Instytutu Polonistyki Stosowanej UW pozwoliło spojrzeć na polonistykę jako na studia łączące filologiczną wiedzę teoretyczną, koncentrująca się na specjalistycznej interpretacji tekstów kultury, z kształceniem praktycznych umiejętności produkowania rozmaitych tekstów oraz lingwistyczną i kulturologiczna wiedzą o ich tworzeniu.

Ten bliski amerykańskim i zachodnioeuropejskim modelom uprawiania studiów językowo-kulturowych sposób realizacji studiów filologicznych zakładał w koncepcji S. Dubisza rozłożenie akcentów kształcenia na trzy filary. Dominująca wśród nich „praktyczność” przekładania i nauczania wiedzy polonistycznej opierała się na „doświadczeniu” praktycznym wykładajacych, otwartych na "nowoczesne potrzeby” studiujacych [por. Dubisz 2017]. Tak skonstruowany know how akademicki postrzegał siłę swojego oddziaływania i sprawczości w

kształceniu praktycznych umiejętności formułowania (produkowania, konstruowania) różnego typu tekstów (komunikatów, przekazów) w języku polskim - z uwzględnieniem ich uwarunkowań kontekstowych - oraz jako wiedzy o tych mechanizmach i procesach [Dubisz 2017, 11].

Tak sformułowana definicja polonistyki stosowanej wymagała w kontekście metodologicznym podejścia inter- i transdyscyplinarnego i tym samym zakładała współpracę różnych obszarów szeroko rozumianej polonistyki oraz innych nauk humanistycznych, społecznych, ale także innych, m.in. medycznych, pod szyldem nowego obszaru działalności akademickiej.

Skonstruowana przez S. Dubisza mapa współdziałania owych obszarów w odniesieniu do ośmiu zdefiniowanych kontekstów zawodowych polonistyki stosowanej, które stały się przedmiotem i celem wdrażanych specjalizacji zawodowych, wygląda następujaco:

Edytorstwo (Językoznawstwo + Literaturoznawstwo) Stylistyka (Językoznawstwo + Literaturoznawstwo) Retoryka (Językoznawstwo + Literaturoznawstwo) Wiedza o mass mediach (Językoznawstwo + inne) Edukacja (Językoznawstwo + Literaturoznawstwo) 
Logopedia (Językoznawstwo + Pedagogika + Medycyna + Psychologia) Glottodydaktyka (Językoznawstwo + Pedagogika + Historia) Translatologia (Językoznawstwo + Literaturoznawstwo + teoria informacji i komunikacji) [tamże, 19].

Akademickie funkcjonowanie warszawskiego Instytutu Polonistyki Stosowanej skupione jest w wyżej wymienionych obszarach, w ramach których istnieje pięć zakładów badawczo-dydaktycznych (2021): Zakład Edukacji Polonistycznej i Kształcenia Ustawicznego, Zakład Edytorstwa i Stylistyki, Zakład Komunikacji Językowej i Glottodydaktyki, Zakład Logopedii i Emisji Głosu, Zakład Retoryki i Mediów oraz osiem pracowni naukowych: Pracownia Językoznawstwa Stosowanego, Pracownia do Badań Historii i Teorii Retoryki, Pracownia Badań Edukacji Polonistycznej i Medialnej, Pracownia Pragmatyki i Semantyki Lingwistycznej, Pracownia Fonetyki Stosowanej im. Marii Przybysz-Piwko, Pracownia Dziejów Polonistyki Warszawskiej, Pracownia Retoryki Stosowanej oraz Obserwatorium Etyki Słowa.

Rozwój metodologicznych podejść inter- i transdyscyplinarnych $z$ coraz większym przekonaniem pozwala nam dziś na dodawanie nowych segmentów badawczych do poszczególnych obszarów uprawiania polonistyki stosowanej. Choć zahaczają one w pierwszej kolejności o subdziedziny polskiej lingwistyki stosowanej, warto byłoby przyjrzeć się im świadomie także $z$ perspektywy tzw. lingwistyk łącznikowych, które musza przecież być także obecne w szerokim spojrzeniu S. Dubisza.

Samą koncepcję polonistyki stosowanej, w swej pierwotnej wersji „zahaczajaca” o glottodydaktykę, warto byłoby uzupełnić o kierunki i sposoby realizacji studiów polonistycznych za granicą. Szczególnie dalekowschodni, azjatycki sposób ich uprawiania (polonistyka koreańska, chińska) od samego początku realizowany był w sposób nader aplikatywny. Pisząc zatem o polonistyce stosowanej, należałoby także uwzględnić doświadczenia zagranicznych ośrodków, które dawno już zerwały $z$ tradycyjnym sposobem uprawiania filologicznych studiów polonistycznych (albo nigdy go nie doświadczyły) znanych nam $z$ własnego podwórka akademickiego. S. Dubisz w swoich rozważaniach, w dużym stopniu glottodydaktycznych, nie sięgnął bezpośrednio po rozwiązania polonistyk zagranicznych. Nietrudno dziwić mu się, skoro weźmiemy pod uwagę fakt, że jeszcze całkiem niedawno (do lat 90. minionego stulecia) polonistyka krajowa niezbyt często i bez szczególnego uznania przyglądała się uprawianiu badań nad naszym językiem za granicą. Takie inicjatywy jak powołanie stowarzyszenia „Bristol”, zrzeszajaccego zagranicznych i polskich polonistów (1997), miały na celu zmianę panującej sytuacji i otworzyły nowe perspektywy współpracy, która dziś powoli zaczyna być czymś naturalnym. 


\section{POLONISTYKA STOSOWANA \\ A LINGWISTYKA STOSOWANA I JĘZYKI STOSOWANE}

Dla większości lingwistów pierwotna koncepcja polonistyki stosowanej Stanisława Dubisza zbliżona jest do polskiej lingwistyki stosowanej. Polonistka $z$ wykształcenia, ale pracująca w środowisku lingwistów neofilologów Ewa Gruszczyńska, tak interpretuje realizowana w Instytucie Polonistyki Stosowanej koncepcję S. Dubisza: Polonistyka stosowana [to - PG]:

prowadzenie, organizowanie oraz rozwijanie polonistycznych specjalności i specjalizacji zawodowych oraz badań naukowych powiazanych zarówno $z$ problematyka stosowanych dyscyplin lingwistycznych oraz z szeroko pojmowana problematyka z zakresu wiedzy o języku polskim [Gruszczyńska 2014, 96].

Obszar ten traktowany jest zatem jako swoisty nowy typ lingwistyki stosowanej i nadrobienie zaległości, jakie można zarzucić środowisku polonistów, porównując je $z$ innymi rodzimymi lingwistykami, uprawianymi w krajach zachodnich. W ich wypadku, jak zauważa E. Gruszczyńska, lingwistyka stosowana obejmuje swoim zasięgiem wszystkie języki, także rodzime [tamże]. Taka akademicka organizacja lingwistyki stosowanej doprowadziła do sytuacji nierównomiernego i nieporównywalnego poziomu zainteresowania oraz sposobu uprawiania poszczególnych obszarów lingwistyki stosowanej w Polsce w kręgach neofilologicznych i polonistycznych, na korzyść tych pierwszych:

Jednak [badania w zakresie lingwistyki stosowanej - PG] były i sa w dalszym ciagu prowadzone na gruncie języków obcych, gdyż w sposób naturalny pracownicy naukowi lingwistyk stosowanych wywodzą się z kręgu filologów obcych. W związku $z$ tym poza ich polem działań znajduje się wszystko lub prawie wszystko, co wiąże się $z$ językiem rodzimym [tamże].

Często jednak i neofilologicznie zorientowani lingwiści zaczynają się interesować danym obszarem w odniesieniu do języka rodzimego, co miało miejsce m.in. w zakresie krytycznej analizy dyskursu w Instytucie Lingwistyki Stosowanej UW nastawionej pierwotnie na kontekst angielskojęzyczny, $z$ czasem jednak uzupełniony o polskojęzyczny dyskurs medialny, co zaowocowało powołaniem przez Annę Duszak i Łukasza Kumięgę z Instytutu Lingwistyki Stosowanej UW we współpracy z Instytutem Socjologii studiów interdyscyplinarnych „Język i społeczeństwo interdyscyplinarne badania nad dyskursem”, prowadzonych po polsku we współpracy z Wydziałem Socjologii (tamże).

Choć E. Gruszczyńska w swoim tekście wydaje się zachęcać do bliższej współpracy lingwistów stosowanych z polonistami i polonistów $z$ lingwistami, nie zauważa, że tego typu praktyki realizowane już były dużo wcześniej na polu jednego $z$ obszarów lingwistyki stosowanej, którym jest glottodydaktyka. Stanowiąca swoiste uzupełnienie polskich szkół lingwistyki stosowanej krakowska szkoła glottodydaktyki polonistycznej 
Władysława T. Miodunki właśnie w symbiozie glottodydaktyki polonistycznej z glottodydaktyka neofilologiczną i w transferze myśli naukowej oraz europeizacji nauczania polszczyzny znalazła swoją drogę funkcjonowania i rozwoju. Owe praktyki wdrażane od końca lat 70. minionego stulecia, polegające na zatrudnianiu neofilologów zajmujących się badaniami i nauczaniem cudzoziemców polszczyzny, tak podsumował dwadzieścia lat później W.T. Miodunka:

Neofilolodzy wnosili dobre przygotowanie $z$ metodyki nauczania języków obcych, dobrą znajomość co najmniej dwu języków obcych oraz językową kompetencję native speakera w zakresie znajomości języka polskiego. (...) Tym, co okazało się bardzo użyteczne w praktyce prowadzenia badań i nauczania, było większe uczulenie neofilologów na nowe prady w lingwistyce, na socjo- i psycholingwistykę, na pragmalingwistykę i teorię tekstu, na nowe metodologie i techniki, także - technologie [Miodunka 1999, 36].

Skuteczne akademickie działania W.T. Miodunki i rozwój glottodydaktyki polonistycznej w dużym stopniu zapewniły mariaż polonistów $z$ neofilologami o inklinacjach lingwistycznych. Poczatek tak obranej drogi zaczą się od pobytu W.T. Miodunki na początku lat 70 . XX w. we Francji, gdzie studiował lingwistyke stosowana pod kierunkiem zwolenników tego nurtu uprawiania językoznawstwa dla potrzeb rozwoju nauczania języka francuskiego jako obcego. Krakowska szkoła glottodydaktyki polonistycznej została zatem w dużym stopniu zainspirowana badawczymi i metodologicznymi koncepcjami zachodnioeuropejskimi. Jej sukces przekładający się na szereg osiągnięć glottodydaktyki polonistycznej, uprawianej w dużym stopniu na poziomie zbliżonym do praktykowania nauczania bardziej popularnych i wartościowych komunikacyjnie języków zachodnich, nie znalazł szybko zwolenników w innych, pokrewnych obszarach lingwistyki stosowanej. Komparatywizm, leżący u podłoża krakowskiej koncepcji rozwoju glottodydaktyki polonistycznej, pojawia się w pewien sposób, choć $z$ nieco innym polem zasięgu i wektorami transferu myśli naukowej, dopiero z początkiem XXI wieku w wizji S. Dubisza. Polonistyka stosowana stanowi tym samym swoista koncepcje o charakterze porównawczym, opierająca się na swobodnym, ale jednak w dużym stopniu programowanym transferze osiagnięć i koncepcji badawczych $z$ lingwistyki stosowanej do obszaru polszczyzny.

\section{FILOLOGIA I LINGWISTYKA STOSOWANA (JĘZYKI STOSOWANE) W KONTEKŚCIE EUROPEJSKIM}

W rzeczywistości zachodnioeuropejskiej uprawianie stosowanych studiów językowo-kulturowych oraz studiów regionalnych stanowi ważny, praktykowany od dawna element akademickiego kształcenia językowego; zarówno w odniesieniu do języków ojczystych, jak i obcych, a i często obu powiazanych ze soba pod szyldem szeroko pojmowanej lingwistyki 
stosowanej lub języków stosowanych. I tak, dla przykładu, studia w zakresie Angewandte Germanistik (germanistyki stosowanej) oferuja wgląd w różne obszary praktyki zawodowej, do której daje dostęp i uprawnia zawodowo ukończenie studiów germanistycznych. Studenci dowiadują się, na jaką wiedzę i umiejętności jest zapotrzebowanie w poszczególnych dziedzinach lingwistycznych, także w ujęciach inter- i transdyscyplinarnych we współpracy $z$ innymi dziedzinami nauk. Reformowane w ostatnich latach studia germanistyczne tego typu prowadzone sa m.in. na niemieckich i austriackich uniwersytetach w Rostocku, Chemnitz, Getyndze, Würzburgu, Innsbrucku i Klagenfurcie.

Samo określenie Angewandte Germanistik stało się także punktem odniesienia dla zwykle tradycyjnie zorientowanych filologicznie germanistyk (w ramach języka niemieckiego jako obcego) uprawianych głównie w krajach Europy Środkowej, Wschodniej i Południowej. W tej koncepcji upatruje się szansy na reformę tego kierunku studiów, który cieszy się coraz mniejszym zainteresowaniem, choć często proponuje zorientowane zawodowo kształcenie nauczycieli i tłumaczy, wykraczajace poza tradycyjny model uprawiania filologii. Powołane w trakcie konferencji w Bukareszcie w roku 2017 Stowarzyszenie Germanistyki Stosowanej (Verband der Angewandten Germanistik), mające na celu wspieranie reform tradycyjnie uprawianej germanistyki, definiuje germanistykę stosowana jako obszar transdyscyplinarny. Jej celem jest badanie warunków zachodzenia, rozpowszechniania i mediacji procesów komunikacji pisemnej i ustnej, jak również wzajemnego oddziaływania literatury, mediów, polityki i społeczeństwa. W ten sposób integruje ona już ugruntowane obszary badawcze germanistyki, takie jak regionalny (uwarunkowany politycznie) i migracyjny wymiar zmian językowych zachodzących w języku niemieckim w obrębie zamkniętego niemieckiego obszaru językowego i poza nim, ale także nowe obszary, takie jak lingwistyka migracyjna, mediacja literatury w epoce elektronicznej czy lingwistyka polityczna [por. Gädeanu 2017; 2019]. To swoiste powiazanie germanistyki rodzimej z jej uprawianiem w obszarze funkcjonowania języka niemieckiego jako obcego można interpretować także jako praktyki transdyscyplinarne, wdrażane ponad lokalnymi kulturowymi uwarunkowaniami prowadzenia filologicznej działalności akademickiej, ale $z$ odniesieniami do nich i ich racjonalnym wykorzystywaniem.

Opisywane praktyki germanistyczne można także zaobserwować w wypadku innych języków i filologii zachodnioeuropejskich, także w rzeczywistości języków romańskich (zwykle uprawiane pod postacią języków stosowanych we Francji i Szwajcarii francuskojęzycznej: langues [étrangères] appliquées; we Włoszech: linguistica applicata i scienze di linguaggio, w Hiszpanii: lingüistica aplicada, w Portugalii: linguas [estrangeiras] aplicadas). W wypadku krajów anglosaskich studia w zakresie lingwistyki stosowanej, prowadzone od lat 50. minionego stulecia, obejmują dziś w swoim formacie dydaktycznym szerokie spektrum opisywanych przez nas subdziedzin lingwistyki stosowanej (głównie $z$ perspek- 
tywy lingwistyk łacznikowych) w powiąaniu $z$ innymi dziedzinami nauk, w ujęciu aplikatywnym. Studiuje się zatem coraz częściej lingwistykę stosowana w powiazaniu $z$ ekonomia, zarządzaniem, prawem, naukami o mediach, politologia, socjologia itp. kombinacjami, zarówno w odniesieniu do języka angielskiego, jak i języków obcych (często równocześnie w obu wymiarach, także w kontekście porównawczym).

\section{INTER- I TRANSDYSCYPLINARNOŚĆ BADAŃ Z ZAKRESU LINGWISTYKI I POLONISTYKI STOSOWANEJ}

Wprowadzanie metodologicznej perspektywy inter- i transdyscyplinarności do dociekań naukowych z zakresu lingwistyki stosowanej staje się jednym $z$ warunków dalszego rozwoju tego obszaru badań. Podczas gdy interdyscyplinarność przyjęło się zwykle rozumieć jako swoista pracę na styku dyscyplin, która polega na wykorzystywaniu teoretycznych kategorii i metod badawczych różnych dyscyplin w celu opisania tego samego zjawiska lub problemu, transdyscyplinarność opisuje proces, w którym systematyczna praca naukowa prowadzona jest $\mathrm{z}$ wielu perspektyw $\mathrm{w}$ konkretnych przestrzeniach wybranych podejść metodologicznych, pytań badawczych, których złożoność sprawia, że są konieczne do wprowadzenia wieloperspektywiczne syntezy [Chouliaraki, Fairclough 1999].

Interdyscyplinarność stanowiąca swoisty kontrapunkt dla tradycyjnego, wciąż jeszcze obecnego mentalnie podziału nauk na różne dyscypliny, pozwalającego zgłębiać tajniki zjawisk w ich szczegółach i nieuwzględniającego powiązań między zachodzącymi w świecie dynamicznymi zjawiskami, owocowała zwykle współpraca specjalistów reprezentujących różne dziedziny badawcze.

Podejście transdyscyplinarne należy rozumieć jako swoisty dialog dyscyplin i teorii, które staja się inspiracją rozwoju teoretycznego i metodologicznego [Fairclough 2005].

Spotykające się ze soba w owym dialogu dyscypliny i teorie rozwijaja się dalej w obrębie swoich wymiarów koncepcyjnych i perspektyw ich aplikacji. Współpraca tych dyscyplin prowadzi docelowo do nowego, systemowego porządku, zmieniającego i rozwijającego owe dziedziny [Mittelstraß 2005]. Owa produktywna transformacja odbywa się na zasadzie swoistego „przekładu” różnych elementów nauki:

Umieszczanie kategorii jednej teorii w ramach innej wiąże się $z$ procesem przekładu - lub mówiąc inaczej $z$ redukowaniem istotnych różnic między teoriami w odniesieniu do obiektów własnych i łączącej ich logiki [Chouliaraki, Fairclough 1999, 112; tłumaczenie własne].

Zarówno podejścia inter-, jak i transdyscyplinarne stanowia dzisiaj zasadniczy metodologiczny punkt odniesienia realizowanych projektów empirycznych w obszarze lingwistyki stosowanej. 
Dla koncepcji polonistyki stosowanej szczególnie szersze włączanie perspektywy transdyscyplinarnej powinno przyspieszyć jej wyjście poza ramy tradycyjnej filologii polskiej. Może stać się zabiegiem zbliżającym polska polonistykę do polonistyk zagranicznych, które w swoich stadiach rozwoju często uwikłane są w lokalne, bardziej aplikatywne modele uprawiania studiów językowych. Warto owa perspektywę traktować jako punkt odniesienia do podejmowania nowych projektów badawczych i tworzenia nowych ścieżek studiów, daleko wykraczających poza nauki humanistyczne i społeczne, tym samym przyczyniając się do wzmacniania procesów komunikacji we wszelkich działaniach ludzkich.

\section{POLONISTYKA STOSOWANA JAKO INTEGRUJĄCA KONCEPCJA BADAWCZA}

Integrująca koncepcję badawczą należy rozumieć jako świadomą wolę współpracy naukowej specjalistów reprezentujących różne dziedziny polonistyki (zarówno o nachyleniu językoznawczym, literaturoznawczym, jak i kulturoznawczym), poszczególne obszary lingwistyki stosowanej i polonistycznej oraz specjalistów różnych, czasem pozornie odległych od siebie dyscyplin w obszarze konkretnych kontekstów komunikacji i działania $z$ użyciem polszczyzny.

W myśl podjętych w niniejszym tekście rozważań można przyjać, że polonistyka stosowana stanowi inter- i transdyscyplinarny obszar badawczy, który jednak w obszarze kształcenia akademickiego powinien rozwijać się jako autonomiczny kierunek studiów, łączący programowo polonistykę $z$ innymi dziedzinami i kierunkami studiów, $z$ uwzględnieniem postępu cywilizacyjnego i zmieniających się potrzeb studiujących, wynikajacych $z$ rozwoju nowych zawodów, wymagających akademickiego wykształcenia polonistycznego.

Dzisiejszy stan rozwoju myśli naukowej w zakresie polonistyki stosowanej, uwzględniający pierwotna koncepcję Stanisława Dubisza, stanowi swoisty mariaż reformującej się filologii polskiej z polską koncepcja lingwistyki stosowanej (zob. rys. 1.).

Pisząc o pełnej i wartościowej teorii czy koncepcji naukowej, warto sprawdzić, czy składa się ona w złożoną hierarchiczno-sieciową strukturę $z$ trzema dającymi się wyróżnić poziomami. Sa nimi: zespół założeń ontologicznych, epistemologiczno-metodologicznych i aksjologicznych, w dużej mierze stanowiących przyjęta bazę filozoficzna; zespół wysoce abstrakcyjnych pojęć teoretycznych i ogólnych twierdzeń, które selektywnie konceptualizuja i strukturalizują rzeczywistość, tworząc szczególny, interpretacyjny obraz oraz zespół pojęć i twierdzeń opisowych (obserwacyjnych), orzekających coś bezpośrednio o badanych obiektach i tworzących część empiryczną [Gajda 2016, 25]. 


\section{Rys. 1. Współczesna koncepcja polonistyki stosowanej [opracowanie wlasne, por. Dubisz 2007; 2017]. \\ POLONISTYKA STOSOWANA \\ PONAD FILOLOGIĄ I LINGWISTYKĄ STOSOWANĄ \\ Mariaż dwóch koncepcji}

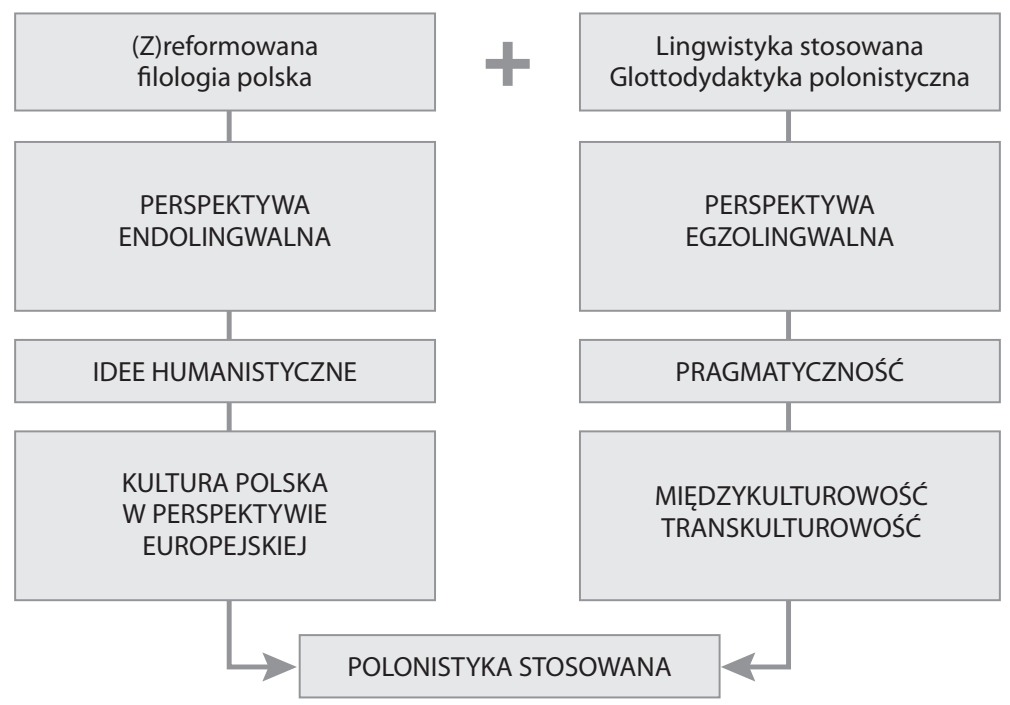

Koncepcja polonistyki stosowanej w swojej bazie filozoficznej łączy ze sobą współczesne idee humanistyczne z pragmatyką działania językowego i komunikacji, które wchodza ze soba w swoisty mariaż, realizowany w inter- $\mathrm{i}$ transdyscyplinarnych kontekstach metodologicznych, w obszarach lingwistyk łącznikowych, pokrywających się z tymi rozwijanymi w ramach lingwistyki stosowanej (patrz określenia nazw zakładów naukowych i pracowni warszawskiego Instytutu Polonistyki Stosowanej UW). Konceptualizacja i strukturalizacja rzeczywistości komunikacji językowej obejmuje funkcjonowanie (używanie) polszczyzny, zarówno w otoczeniu endo-, jak i egzolingwalnym. Europejski kulturologiczny wymiar filologii polskiej rozszerzony zostaje o ujęcia między- i transkulturowe, otwierające polonistykę na rzeczywistość komunikacji i kulturowej współpracy w ujęciach globalnych.

Współczesna polonistyka stosowana nie jest obszarem badawczym $z$ samodzielna metodologia, lecz inter- i transdyscyplinarnym programem badawczym, który warto jednak rozwijać pod szyldem dziedziny zabiegającej o swoja autonomię akademicką. Czerpie $z$ rozwoju obszarów badawczych rozwijanych w jej ramach (w ujęciu łącznikowym lub $\mathrm{w}$ ujęciu polskiej lingwistyki stosowanej) oraz $\mathrm{z}$ przemian zachodzacych $\mathrm{w}$ humanistyce. Jej powiazania $z$ literaturo- i kulturoznawstwem polo- 
nistycznym czynią zeń dziedzinę wykraczająca poza lingwistykę stosowana, której nie jest i nie będzie jedynie polonistycznym segmentem. Realizując swoje specyficzne zadania i właściwe sobie cele poznawcze, postrzega siebie jako koncepcję badawcza integrująca i projektowa, łącząca ze sobą różne perspektywy teoretyczne i metodologiczne w obszarze projektowania swoich celów poznawczych, przedmiotu badań, procedur badawczych i aparatu pojęciowego.

To, w jaki sposób dzisiejsza polonistyka stosowana ujawnia się na arenie współczesnych nauk humanistycznych wymaga szczegółowych analiz uwzględniających cztery wymiary: instytucjonalny, substancyjny, tematyczny i ukryty ideologiczny [por. Czachur 2020]. Uzyskanie odpowiedzi na pytania uwzględniające wszystkie wymienione wymiary ułatwi określenie jej pozycji, wpływu i siły oddziaływania na inne dyscypliny humanistyczne oraz zaprogramuje dalszy jej rozwój jako względnie autonomicznego obszaru badawczego i dydaktycznego.

Warto też pamiętać, że istotnym elementem dalszego rozwoju tej stosunkowo młodej wciąz koncepcji jest utożsamianie się polonistów $z$ samą koncepcja i tym samym współtworzenie wspólnoty dyskursywnej badaczy z nią się utożsamiających. W trakcie konstytuowania się każdego obszaru badawczego decydujaca rolę odgrywa identyfikowanie się badaczy, którzy ją uprawiaja, z koncepcjami i założeniami metodologicznymi leżącymi u podłoża jej powstania i rozwoju. Wpływa to na kształtowanie się tożsamości nowej dziedziny (i reprezentującej jej wspólnoty badaczy), wzmacnia ją od wewnątrz i przyspiesza proces uznania przez zewnętrzne środowiska naukowe. Takie uznanie jest zwykle istotnym pierwszym gwarantem procesu autonomizacji danej dziedziny, który zapowiada jej rychły dalszy sukces [por. Gębal 2013].

Terminem polonistyka stosowana zainteresowali się już badacze związani $z$ innymi ośrodkami naukowymi. Samodzielne studia na kierunku polonistyka stosowana sa dzisiaj prowadzone na Uniwersytecie Rzeszowskim. Zakłady Polonistyki Stosowanej funkcjonuja w strukturach Instytutu Filologii Polskiej Uniwersytetu Gdańskiego i Instytutu Polonistyki i Kulturoznawstwa Uniwersytetu Opolskiego.

Warto zadbać o dalszy rozwój polonistyki stosowanej, integrując ze sobą reprezentantów różnych ośrodków ją uprawiających i realizujących dydaktycznie. Tego zadania powinien się podjać warszawski Instytut Polonistyki Stosowanej UW, w którym opisywana koncepcja dzięki pierwotnej idei Stanisława Dubisza się zrodziła i uzyskała formalny akademicki mandat instytucjonalny w postaci autonomicznej naukowo jednostki uniwersyteckiej. 


\section{Bibliografia}

G.P. Bąbiak (red.), 2017, Doświadczenie, praktyczność, nowoczesność. Dziesięć lat Instytutu Polonistyki Stosowanej na Wydziale Polonistyki UW, Warszawa.

L. Chouliaraki, N. Fairclough, 1999, Discourse in late modernity: Rethinking Critical Discourse Analysis, Edinburgh.

W. Czachur, 2020, Lingwistyka dyskursu jako integrujacy program badawczy, Wrocław.

S. Dubisz, 2006, Filologia polska-glottodydaktyka polonistyczna-polonistyka stosowana [w:] D. Knysz-Tomaszewska, J. Porayski-Pomsta, K. Wrocławski (red.), Na chwałe i pożytek nasz wzajemny. Złoty jubileusz Polonicum, Warszawa, s. 161-172.

S. Dubisz, 2013, Teoria lingwistyczna w językoznawstwie stosowanym - na przykładzie glottodydaktyki polonistycznej, „Poradnik Językowy” z. 1, s. 15-23.

S. Dubisz, 2017, Instytut Polonistyki Stosowanej - pierwsza dekada [w:] G.P. Babiak (red.), Doświadczenie, praktyczność, nowoczesność. Dziesięć lat Instytutu Polonistyki Stosowanej na Wydziale Polonistyki Uniwersytetu Warszawskiego, Warszawa, s. 9-42.

A. Duszak, 1998, Tekst, dyskurs, komunikacja międzykulturowa, Warszawa.

A. Duszak, 2009, O władzy języka, słabości lingwistyki i potrzebie krytycznej analizy dyskursu, „UW. Pismo uczelni” 1, s. 12-13.

A. Duszak, N. Fairclough (red.), 2008, Krytyczna analiza dyskursu: interdyscyplinarne podejście do komunikacji społecznej, Kraków.

A. Duszak, J. House, Ł. Kumięga (red.), 2010, Globalization, Discourse, Media: In a Critical Perspective / Globalisierung, Diskurse, Medien: eine kritische Perspektive, Warszawa.

N. Fairclough, 2006, Critical Discours Analysis in trans-disciplinary research an social change: transition, re-scaling, poverty and social inclusion, „Lodz $\mathrm{Pa}-$ pers in Pragmatics" 1, s. 37-58.

S. Gajda, 2016, Granice języka a granice językoznawstwa, „Biuletyn Polskiego Towarzystwa Językoznawczego" 72, s. 23-36.

P.E. Gębal, 2013, Modele kształcenia nauczycieli języków obcych w Polsce i w Niemczech. W stronę glottodydaktyki porównawczej, Kraków.

P.E. Gębal, 2014, Krakowska szkoła glottodydaktyki porównawczej na tle rozwoju glottodydaktyki ogólnej i polonistycznej, Kraków.

P.E. Gębal, 2019, Dydaktyka języków obcych. Wprowadzenie, Warszawa.

F. Grucza, 1983, Zagadnienia metalingwistyki. Lingwistyka-jej przedmiot, lingwistyka stosowana, Warszawa.

F. Grucza, 2007, Lingwistyka stosowana. Historia-zadania-osiagnięcia, Warszawa.

F. Grucza, 2009, Metanaukowa i metalingwistyczna wizja lingwistyki (stosowanej), „Lingwistyka Stosowana / Applied Linguistics / Angewandte Linguistik” nr 1, s. 19-39.

S. Grucza, 2009, O nieporozumieniach $w$ sprawie siły lingwistyki, „Lingwistyka Stosowana. Przeglą" 1, s. 99-113.

E. Gruszczyńska, 2014, Lingwistyka stosowana a polonistyka stosowana: podobieństwa i różnice, „Lingwistyka Stosowana. Przegląd” 9, s. 93-101.

D. Kubinowski, M. Chutorański (red.), 2017, Pedagogika jako humanistyczno-społeczna nauka stosowana: konsekwencje metodologiczne, Kraków. 
Ł. Kumięga, P.E. Gębal, 2020, O inter- $i$ transdyscyplinarnych powiazaniach lingwistyki (stosowanej) z badaniami nad językiem, translatoryka i literaturoznawstwem [w:] Ł. Kumięga, P.E. Gębal (red.), Lingwistyka interdyscyplinarnie. Konteksty językowe, tłumaczeniowe i literackie, Torun, s. 5-14.

W.T. Miodunka, 1999, Od Studium Języka Polskiego do Zakładu Językoznawstwa Stosowanego. 20 lat kształcenia cudzoziemców w Instytucie Polonijnym UW [w:] W.T. Miodunka, J. Rokicki (red.), Oswajanie chrzaszcza w trzcinie, czyli o kształceniu cudzoziemców w Instytucie Polonijnym UJ, Kraków, s. 34-48.

J. Mittestraß, 2005, Methodische Transdisziplinarität, „Technikfolgenabschätzung. Theorie und Praxis" 2(14), s. 18-23.

M. Ogrodniczuk, 2017, Lingwistyka komputerowa dla języka polskiego: dziś i jutro, „Język Polski” nr 97, s. 18-28.

L. Zabrocki, 1966, The Institute of Applied Linguistics at the Adam Mickiewicz University, „Glottodidactica” nr 1, s. 131-135.

\section{More than philology and applied linguistics. Applied Polish studies as an integrative research concept}

Summary

Applied Polish studies are a currently developed research area and university teaching practice combining the traditional philological Polish studies with other scientific disciplines based on inter- and transdisciplinary academic collaboration principles to meet the needs arising from the performance of tasks assigned to specific professions requiring a background in Polish studies in the field of linguistic, literary and cultural studies. Originally developed by Stanisław Dubisz, the concept became a stimulus for establishing the Institute of Applied Polish Studies at the University of Warsaw and similar units at other Polish universities. This text shows the potential of a continued support for the development of applied Polish studies as an integrative research concept and associates it with the concepts of the Polish applied linguistics and applied languages studied at Western European universities.

Keywords: Polish philology - applied Polish studies - applied linguistics applied languages - research area - inter- and transdisciplinarity 